Article

\title{
Vitamin D and Abdominal Aortic Calcification in Older African American Women, the PODA Clinical Trial
}

\author{
Saloni Brahmbhatt ${ }^{1}$, Mageda Mikhail ${ }^{2}$, Shahidul Islam ${ }^{3}$ and John F. Aloia ${ }^{1, *(1)}$ \\ 1 Bone Mineral Research, NYU Winthrop Hospital/NYU Langone Health, Mineola, NY 11501, USA; \\ saloni.brahmbhatt88@gmail.com \\ 2 Department of Endocrinology, NYU Winthrop Hospital/NYU Langone Health, Mineola, NY 11501, USA; \\ Mageda.Mikhail@nyulangone.org \\ 3 Biostatistician, NYU Winthrop Research Institute, NYU Long Island School of Medicine, \\ NYU Langone Health, Mineola, NY 11501, USA; Shahidul.Islam@nyulangone.org \\ * Correspondence: John.Aloia@nyulangone.org; Tel.: +1-516-663-2442; Fax: +1-516-663-3813
}

Received: 28 February 2020; Accepted: 20 March 2020; Published: 24 March 2020

\begin{abstract}
Abdominal aortic calcification (AAC) detected on lateral vertebral fracture assessment is associated with increased cardiovascular risk. Vitamin D deficiency and toxicity have been linked with vascular calcification. The objective of this study was to determine the effect of high-dose vitamin D on the progression of AAC. The Physical Performance, Osteoporosis and vitamin D in African American Women (PODA) is a randomized, clinical trial examining the effect of vitamin D. There were $14.7 \%$ subjects with AAC in the vitamin D group, compared to $12.1 \%$ in the placebo group at baseline. The prevalence of extended AAC at baseline was $6.4 \%$ in the vitamin D group and $3.5 \%$ in the placebo group. The extended calcification scores over time were not different between groups. There was no association between AAC and serum 25(OH)D. However, PTH was associated with an increase in AAC in the placebo group.
\end{abstract}

Keywords: abdominal aortic calcification (AAC); extended aortic calcification (AAC24); chronic kidney disease (CKD); vertebral fracture assessment (VFA); vascular calcification (VC); dual-energy X-ray absorptiometry (DXA); African American (AA); parathyroid hormone

\section{Introduction}

Both osteoporosis and vascular calcification are common age-related findings in the elderly [1-4]. Vitamin D, interestingly, has been linked with both these processes. Vitamin D has a pivotal role not only in bone metabolism, but also in the vasculature, and may be involved in the process of vascular calcification [5-7]. Experts have emphasized the role of both vitamin D deficiency and excessive vitamin $\mathrm{D}$ in vascular toxicity, indicating a biphasic cardiovascular dose-response curve with deleterious consequences of vitamin D deficiency or excess [5-10]. Excessive vitamin D can induce vascular calcification, which can be reversed by reducing vitamin D activity [11-13]. It has been proposed that osteoporosis and vascular calcification have common pathophysiologic mechanisms [14].

Abdominal aortic calcification (AAC), is significantly predictive of overall cardiovascular disease incidence and mortality (e.g., coronary heart disease, stroke, congestive heart failure, and peripheral vascular disease) independently of classical risk factors [15-19]. AAC is also a marker of subclinical atherosclerotic disease, including coronary artery disease. It has been shown that the calcification of any artery or cardiac valve increases the risk of cardiovascular events and mortality fourfold [17,18,20-23]. Several longitudinal studies have found low plasma concentrations of $25(\mathrm{OH}) \mathrm{D}$, associated with 
an increased risk of cardiovascular events [5,8-10]. A close relationship has also been noted between 25(OH)D and endothelial function [24,25].

Low levels of vitamin D are highly prevalent in chronic kidney disease (CKD) patients and several longitudinal studies have shown that 25(OH)D levels affect mortality independently of vascular calcification and stiffness. [23,26-30]. There are contrasting reports on the effect of vitamin D supplementation on vascular calcification. Some say that supplementation with Vitamin D accelerates atherosclerosis, while others support the notion that vitamin D supplementation can reverse or halt the progression of vascular calcification [11,12,31,32].

The effect of vitamin D supplementation has been studied less in healthy persons. The PODA trial had the prevention of bone loss and decline in physical performance by an intake of vitamin D sufficient to maintain $25(\mathrm{OH}) \mathrm{D}$ above $75 \mathrm{nmol} / \mathrm{L}$ as its primary aims [33-35]. For this report, we measured AAC every 12 months for three years to determine if high-dose vitamin D supplementation affected the progression of AAC in older African American women. We also wanted to explore the relationship between AAC and bone turnover markers and PTH. Some of these data were presented at an annual meeting of the Endocrine Society [36].

\section{Material and Methods}

The physical performance, osteoporosis prevention and vitamin D in older African Americans (PODA) study is a prospective, randomized, double-blind, placebo-controlled, three-year clinical trial of vitamin D3 supplementation in AA women older than 60 years of age [33]. Baseline demographics and laboratory values and some results have been reported in previously published papers $[33,34,37-40]$. In this paper, we report the results of AAC, which was a pre-specified secondary outcome. Written informed consent was obtained from each participant and the trial was approved by the Winthrop IRB and monitored by a Data Safety Monitoring Board appointed by the National Institutes of Aging. The trial was registered as NCT01153568 [41].

Healthy participants, self-declared as black, were recruited from the Long Island community. After screening, those who consented and qualified were randomly allocated to one of two groups: vitamin D3 supplementation or placebo. Inclusion criteria were serum $25(\mathrm{OH}) \mathrm{D}$ greater than $20 \mathrm{nmol} / \mathrm{L}$ and less than $65 \mathrm{nmol} / \mathrm{L}$. Block randomization with a block size of four was performed at baseline using a computer-generated (SAS Proc Plan) randomization list. We enrolled 260 participants. Participants returned for follow-up visits every 3 months with bone density and biochemical measurements at baseline and every 6 months for 36 months. VFA images were done annually.

Participants were given either a single capsule of vitamin D or a matching placebo (depending on allocation) to take once daily. Every 3 months, the vitamin D dose was adjusted to maintain serum $25(\mathrm{OH}) \mathrm{D}$ above $75 \mathrm{nmol} / \mathrm{L}$. The dose assignments were made in real time by the research pharmacist in consultation with the Data Coordinating Center. As doses for the active patients were titrated up or down, the blind was maintained by randomly adjusting the placebo doses to match the distribution of changes in the active patients who were at the same point in the study.

The study drug was manufactured by Alcrea Health (Pittsburgh, PA, USA). The capsules were analyzed in batches for their actual content at an independent laboratory. Calcium supplements (CaCO3) were provided, if needed, based on dietary recall, to achieve a total dietary intake of $1200 \mathrm{mg} /$ day in all participants.

Serum samples were stored at $-40{ }^{\circ} \mathrm{C}$ and assayed at baseline and annually for vitamin $\mathrm{D}$ metabolites by the Department of Laboratory Medicine at the University of Washington (Seattle, Washington) (PMID: 22968104, 21768219). Serum 25(OH)D and 1,25(OH)2D were measured by LC-MS/MS. Concentrations of 25(OH)D were standardized to NIST SRM 972a (PMID: 27091017, $22141317)$. The coefficient of variation $(\mathrm{CV})$ of $25(\mathrm{OH}) \mathrm{D}$ measurement is $3.54 \%-4.41 \%$. Serum Bone Specific Alkaline Phosphate was measured by Micro Vue BAP (Quidel Corp. San Diego, CA, USA). The kit for serum CTX was manufactured by Nordic bioscience Diagnostics A/S (Herlev, Denmark). 
The measurement of serum intact PTH was performed by Immulite 2000 Analyzer (Diagnostic Products Corporation, Los Angeles, CA, USA).

The primary specified endpoint for this study was a change in bone mineral density (BMD) of the total femur. Other bone density measurements included: BMD of the trochanter and femoral neck, AP spine, total body, and non-dominant radius. BMD was measured at baseline and every 6 months on a Hologic Discovery a instrument. The same instrument was used throughout the study.

\subsection{Assessment of Aortic Calcification}

All VFA scans were studied by the same reader to assess the presence of AAC. To score AAC extension, we used the score described by Kauppila et al [14,42]. The reader used the same process as described by Schousboe et al. [43]. These scores were measured at 0-, 12-, 24-, and 36-month visits. The reproducibility of the assessment was evaluated by repeated blind readings done by the same reader for all the baseline visits, and the intra-rater correlation was 0.75 .

\subsection{Statistical Analysis}

Block randomization with a block size of four was performed at baseline using a computer-generated (SAS Proc Plan; SAS Institute, Inc., Cary, NC, USA) randomization list. Subjects were assigned to one of two groups: vitamin $\mathrm{D}_{3}$ supplementation or placebo. Any participant who was randomized and received at least one dose of the study medication was included in the intention to treat (ITT) population, and primary analysis was performed according to ITT principle. In the original study design, power was determined based on previous studies and a differential bone mineral density rate of change of $0.18 \%$ or greater per year.

Descriptive statistics were generated and presented as mean \pm standard deviation or median (interquartile range) for the continuous variables, and frequency (percentage) for the categorical variables. The normality of distribution of clinical variables and laboratory markers was examined using a visual inspection of histograms and the Kolmogorov-Smirnov test. Between-group differences for each continuous variable were examined using the nonparametric Wilcoxon rank-sum test for non-normally distributed variables and the two independent samples $t$-test for normally distributed variables. Variables were checked for outliers, and analyses were performed with and without outliers, but output remained similar, so full data were used. The Fisher exact test was used to compare categorical variables between groups.

We defined an AAC 24 score of $\geq 5$ as an extended AAC score. We also used the same as our cut-off because an AAC score of $\geq 5$ has been shown to have a 2.4-fold increased cardiovascular disease risk compared to patients without extended AAC scores [19]. The difference in AAC rate between treatment groups over time was evaluated using a repeated-measures mixed-effects logistic regression model. Random subject specific intercept and an unstructured correlation structure was used to account for within-subject correlation between AAC rate overtime. The model included treatment groups, time and the two-way interaction effect term between time and group as the covariates. Model fit was assessed using fit statistics such as AIC and Pearson Chi-Square/DF. Associations of AAC with 25(OH)D, PTH, CTX, BAP and serum creatinine over time were also evaluated using mixed effects logistic regression models. All calculations were performed using SAS version 9.4 (SAS Institute, Inc., Cary, NC, USA). Results were considered statistically significant when $p<0.05$.

\section{Results}

\subsection{Baseline Demographics and Laboratory Studies}

The average age was $68.2(65.4-72.5)$ years. Body mass index was similar between groups (overall $\left.30(26.5-34.1) \mathrm{kg} / \mathrm{m}^{2}\right)$. Few were current smokers, although $21.5 \%$ in the active group and $23.8 \%$ in the placebo group had smoked previously. In the overall sample, no statistically significant relationship was detected between serum total $25(\mathrm{OH}) \mathrm{D}$ concentration and BMI, calcium intake, BMD, muscle mass, 
percent body fat or measures of physical performance (SPPB balance, gait speed, chair stand score, SPPB total score, grip strength or 6MWD). Median daily calcium intake, including self-prescribed supplements, was 842 (600-1142) $\mathrm{mg} / \mathrm{d}$ in the vitamin D group and 827 (628-1185) $\mathrm{mg} / \mathrm{d}$ in the placebo group. Between-group PTH levels also showed no significant differences. The serum $25(\mathrm{OH}) \mathrm{D}$ values reported were obtained from LC-MS/MS. The mean dose of vitamin D3 in the active group was 3490 $\mathrm{IU} \pm 1465 /$ day. Ninety percent of the active group maintained serum $25(\mathrm{OH}) \mathrm{D}$ above $75 \mathrm{nmol} / \mathrm{L}$.

There were no statistically significant differences in CVD risk factors between the two treatment groups: history of hypertension, hyperlipidemia, type 1 and 2 diabetes Mellitus, history of smoking and alcohol use, BMI, and use of medications such as aspirin and statins. Although the extended AAC value was higher in the vitamin D group, this was not statistically significant.

\subsection{Efficacy of Supplementation on Abdominal Aortic Calcification (AAC)}

Calcification score was dichotomized using AAC score cutoff of $\geq 5$ [19]. There were $14.7 \%$ $(16 / 109)$ subjects with the presence of AAC (calcification score $>0)$ in the vitamin D group compared to $12.1 \%(14 / 116)$ in the placebo group. The prevalence of extended AAC (AAC24 score $\geq 5$ ) at baseline was $6.4 \%(7 / 109)$ in the vitamin D group and $3.5 \%(4 / 116)$ in the placebo group. At 36 months, the prevalence was $12.7 \%$ (9/71) in the vitamin D group and 6.9\% (5/73) in the placebo group. Repeated-measures mixed effects model revealed that overall AAC did not change significantly from the baseline (slope $=0.0237, p=0.091$ for time effect) and was not different between treatment groups over time (non-significant interaction between group and time, slope $=-0.0064, p=0.791$ ) (Table 1 ). Generalized chi-square/Degrees of freedom value 0.71 (value closer to one indicates better fit) for our model assures a good fit.

Table 1. Baseline demographics and clinical characteristics.

\begin{tabular}{|c|c|c|c|c|}
\hline & $\begin{array}{l}\text { Vitamin D } \\
(N=130)\end{array}$ & $\begin{array}{c}\text { Placebo } \\
(N=130)\end{array}$ & $\begin{array}{c}\text { Overall } \\
(N=260)\end{array}$ & $p$-Value ${ }^{a}$ \\
\hline \multicolumn{5}{|l|}{ Demographics and behavioral } \\
\hline Age (years) ${ }^{b}$ & $67.8(65.1-71.5)$ & $69.0(65.4-73.4)$ & $68.2(65.4-72.5)$ & 0.251 \\
\hline $\mathrm{BMI}\left(\mathrm{kg} / \mathrm{m}^{2}\right)^{\mathrm{b}}$ & $30.2(26.4-34.6)$ & $30.0(26.8-33.9)$ & $30.1(26.6-34.1)$ & 0.867 \\
\hline Calcium intake $(\mathrm{mg})^{\mathrm{b}}$ & $842.0(600-1142)$ & $826.5(628.0-1185)$ & $828.0(614.0-1164)$ & 0.857 \\
\hline \multicolumn{5}{|l|}{ Cardiovascular Risk factors } \\
\hline Extended AAC (Score $\geq 5)$ * & $7(6.4)$ & $4(3.4)$ & $11(4.9)$ & 0.363 \\
\hline Smoking History, n (\%) & & & & 0.805 \\
\hline Present & $7(5.4)$ & $5(3.9)$ & $12(4.6)$ & \\
\hline Past & $28(21.5)$ & $31(23.8)$ & $59(22.7)$ & \\
\hline Never & $95(73.1)$ & $94(72.3)$ & $189(72.7)$ & \\
\hline Alcohol History, n (\%) & & & & 0.323 \\
\hline Present & $72(55.4)$ & $83(63.9)$ & $155(59.6)$ & \\
\hline Past & $2(1.5)$ & $2(1.5)$ & $4(1.5)$ & \\
\hline Never & $56(43.1)$ & $45(34.6)$ & $101(38.9)$ & \\
\hline Hypertension, n (\%) & $87(66.9)$ & $89(68.5)$ & $176(67.7)$ & 0.895 \\
\hline Hyperlipidemia, n (\%) & $44(33.9)$ & $45(34.6)$ & $89(34.2)$ & 1.00 \\
\hline Type-I Diabetes, n (\%) & $1(0.77)$ & $0(0)$ & $1(0.38)$ & 1.00 \\
\hline Type-II Diabetes, n (\%) & $17(13.1)$ & $21(16.2)$ & $38(14.6)$ & 0.599 \\
\hline On Aspirin therapy, n (\%) & $33(25.4)$ & $38(29.2)$ & $71(27.3)$ & 0.578 \\
\hline On Statin therapy, n (\%) & $37(28.5)$ & $40(30.8)$ & $77(29.6)$ & 0.786 \\
\hline
\end{tabular}


Table 1. Cont.

\begin{tabular}{|c|c|c|c|c|}
\hline & $\begin{array}{l}\text { Vitamin D } \\
(N=130)\end{array}$ & $\begin{array}{c}\text { Placebo } \\
(N=130)\end{array}$ & $\begin{array}{c}\text { Overall } \\
(N=260)\end{array}$ & $p$-Value ${ }^{a}$ \\
\hline \multicolumn{5}{|l|}{ Laboratory } \\
\hline Free $25 \mathrm{OH}$ Vitamin D (pg/mL) & $4.7 \pm 1.2$ & $4.8 \pm 1.3$ & $4.7 \pm 1.3$ & 0.565 \\
\hline $25(\mathrm{OH}) \mathrm{D}_{3}, \mathrm{ng} / \mathrm{mL}$ & $21.5 \pm 6.5$ & $22.2 \pm 6.9$ & $21.8 \pm 6.7$ & 0.352 \\
\hline $1,25(\mathrm{OH})_{2} \mathrm{D}_{3}, \mathrm{pg} / \mathrm{mL}$ & $52.4 \pm 13.7$ & $52.6 \pm 15.4$ & $52.5 \pm 14.6$ & 0.926 \\
\hline PTH $(\mathrm{pg} / \mathrm{mL})^{\mathrm{b}}$ & $56.1(41.0-73.6)$ & $56.4(39.5-73.8)$ & $56.2(39.8-73.8)$ & 0.977 \\
\hline Serum Ca $(m g / d L)^{b}$ & $9.5(9.3-9.8)$ & $9.5(9.3-9.8)$ & $9.5(9.3-9.8)$ & 0.943 \\
\hline Serum $\operatorname{Cr}(\mathrm{mg} / \mathrm{dL})^{\mathrm{b}}$ & $0.8(0.7-0.9)$ & $0.7(0.6-0.9)$ & $0.8(0.6-0.9)$ & 0.472 \\
\hline Serum $P(m g / d L) b$ & $3.5(3.2-3.8)$ & $3.5(3.2-3.8)$ & $3.5(3.2-3.8)$ & 0.732 \\
\hline
\end{tabular}

${ }^{a}$ For continuous data, p-values are from Wilcoxon rank-sum test for non-normally distributed variables and two independent samples $t$-test for normally distributed variables. For categorical variables, p-values are from Fisher's exact test. ${ }^{\mathrm{b}}$ Not normally distributed; IQR = Inter-quartile range (first quartile-third quartile); SD = Standard Deviation; Normally distributed variables were presented as mean \pm SD and not normally distributed variables were presented as median (IQR). * abdominal aortic calcification (AAC) data available for $N=109$ in the vitamin D group and $N=116$ for the placebo group.

\section{3. $A A C$, Vitamin $D$ and Other Biomarkers}

We examined the relationship between AAC and time-dependent $25(\mathrm{OH}) \mathrm{D}$ levels and other biomarkers, regardless of the treatment group assignment (Table 2). Vitamin D levels over time were not associated with AAC ( $p$ value $=0.220$ for the time and $25(\mathrm{OH})$ D interaction). However, PTH was positively associated with calcification. As PTH increased over time, the odds of calcification (AAC $\geq 5$ ) also increased ( $p$ value $=0.012$ for the time and PTH interaction). Results remained comparable when adjusting the PTH model for Serum ca $x$ Serum P product (Table 2). In addition, when the relationship of PTH with AAC over time was analyzed by group, adjusting for Serum $\mathrm{Ca} \times$ Serum P interaction, time and PTH interactions were significant in both groups. The 'time $\mathrm{x}$ serum $\mathrm{Ca} \times \mathrm{Serum} \mathrm{P}^{\prime}$ product was statistically significant in the Vitamin D group $(p=0.046)$ (Table 3 ).

\subsection{Incidence of Cardiovascular Disease (CVD) Risk Factors}

At baseline, CVD risk factors were not significantly different between groups (Table 1). The incidence of risk factors arising during the study was as follows: $2.3 \%(3 / 130)$ patients developed hypertension (HTN) in each treatment group (Vitamin D and Placebo). A total of 1.5\% (2/130) patients in the placebo group developed diabetes mellitus compared to none in the vitamin $\mathrm{D}$ group. A total of $1.5 \%(3 / 130)$ patients in the placebo group developed hyperlipidemia compared to $0.77 \%(1 / 130)$ in the vitamin D group. Combined CVD risk was calculated: 3.85\% (5/130) patients developed at least one CVD risk factor in the placebo group compared to 3.08\% (4/130) in the vitamin D group, with $R R(95 \%$ CI) for vitamin $\mathrm{D}$ group compared to placebo $=0.80(0.22-2.9), p=1.00$.

The repeated-measures mixed-effects model revealed that overall AAC did not change significantly from the baseline (slope $=0.0232, p=0.094$ for time effect) and was not different between treatment groups over time (non-significant interaction between group and time, slope $=-0.0059, p=0.809$ ). Incident CVD risk factors were not associated with AAC (estimate $=0.6760, p=0.507$ ). Individually, the incidence of CVD was not associated with AAC (estimate $=0.7172, p=0.502$ ). No other biomarkers, such as 1,25(OH)2D, CTX, BAP, and serum creatinine, were associated with the AAC (Table 2). 
Table 2. Mixed effects logistic regression models for AAC (score $\geq 5$ ) using vitamin D metabolites and other biomarkers.

\begin{tabular}{|c|c|c|}
\hline Models & Estimate (Standard Error) & $p$ Value \\
\hline \multicolumn{3}{|l|}{$25(\mathrm{OH}) \mathrm{D}, \mathrm{ng} / \mathrm{mL}$} \\
\hline Time (month) & $0.0466(0.0298)$ & 0.119 \\
\hline 25(OH)D, ng/mL & $0.0463(0.0234)$ & 0.052 \\
\hline Time $\times 25(\mathrm{OH}) \mathrm{D}$ & $-0.0011(0.0009)$ & 0.220 \\
\hline \multicolumn{3}{|l|}{ 1,25(OH)2D, pg/mL } \\
\hline Time (month) & $-0.0010(0.0423)$ & 0.982 \\
\hline $1,25(\mathrm{OH}) 2 \mathrm{D}, \mathrm{pg} / \mathrm{mL}$ & $-0.0248(0.0196)$ & 0.205 \\
\hline Time $\times 1,25(\mathrm{OH}) 2 \mathrm{D}$ & $0.0004(0.0008)$ & 0.599 \\
\hline \multicolumn{3}{|l|}{ PTH, pg/mL } \\
\hline Time (month) & $-0.0468(0.0289)$ & 0.106 \\
\hline PTH, pg/mL & $-0.0226(0.0139)$ & 0.105 \\
\hline Time $\times$ PTH & $0.0014(0.0005)$ & 0.012 \\
\hline \multicolumn{3}{|l|}{ PTH, pg/mL ** } \\
\hline Time (month) & $-0.1183(0.0760)$ & 0.120 \\
\hline $\mathrm{PTH}, \mathrm{pg} / \mathrm{ml}$ & $-0.0236(0.0140)$ & 0.092 \\
\hline Time $\times$ PTH & $0.0015(0.00056)$ & 0.007 \\
\hline Time $\times$ Serum Ca $\times$ Serum $P$ & $0.00193(0.0019)$ & 0.312 \\
\hline \multicolumn{3}{|l|}{ CTX, ng/mL } \\
\hline Time (month) & $0.0098(0.0276)$ & 0.721 \\
\hline CTX, ng/mL & $1.0319(1.0242)$ & 0.314 \\
\hline Time $\times$ CTX, ng/mL & $0.0173(0.0395)$ & 0.661 \\
\hline \multicolumn{3}{|l|}{ BAP, ug/mL } \\
\hline Time (month) & $-0.0308(0.0374)$ & 0.411 \\
\hline $\mathrm{BAP}, \mathrm{ug} / \mathrm{mL}$ & $-0.0563(0.0496)$ & 0.257 \\
\hline Time $\times$ BAP & $0.0027(0.0019)$ & 0.165 \\
\hline \multicolumn{3}{|l|}{ Serum Creatinine, mg/dl } \\
\hline Time (month) & $0.0599(0.0763)$ & 0.433 \\
\hline Serum Creatinine, $\mathrm{mg} / \mathrm{dL}$ & $0.4084(2.7670)$ & 0.883 \\
\hline Time $\times$ Creatinine & $-0.0226(0.0846)$ & 0.790 \\
\hline
\end{tabular}

** Secondary PTH model adjusted for 'Serum $\mathrm{Ca} \times$ Serum $\mathrm{P}^{\prime}$ product.

Table 3. Mixed effects logistic regression models for AAC (score $\geq 5$ ) using PTH and product of serum $\mathrm{C}$ and serum P. Analysis, stratified by group.

\begin{tabular}{ccc}
\hline Models & Estimate (Standard Error) & $p$ Value \\
\hline PTH, pg/mL (Vitamin D group) & & \\
\hline Time $($ month) & $-0.2091(0.0954)$ & 0.029 \\
PTH, pg/mL & $-0.0139(0.0158)$ & 0.380 \\
Time $\times$ PTH & $0.0014(0.00069)$ & 0.042 \\
Time $\times$ Serum Ca $\times$ Serum P & $0.0046(0.0023)$ & 0.046 \\
\hline PTH, pg/mL (Placebo group) & & \\
\hline Time $($ month) & $0.1562(0.1310)$ & 0.234 \\
PTH, pg/mL & $-0.0492(0.0268)$ & 0.067 \\
Time $\times$ PTH & $0.0019(0.00095)$ & 0.041 \\
Time $\times$ Serum Ca $\times$ Serum P & $-0.0072(0.0038)$ & 0.060 \\
\hline
\end{tabular}




\section{Discussion}

High-dose vitamin D did not affect the progression of AAC in older African American women. In patients with chronic kidney disease and end-stage renal disease, low 25(OH)D levels are associated with vascular calcification, cardiovascular morbidity and mortality. However, very few data are available studying the relationship of vitamin D status and vascular calcification in non-chronic kidney disease pa tients. Historically, AA women have a lower prevalence of aortic and coronary calcification compared to Caucasian women, despite having higher cardiovascular events and mortality [44-46]. In the multi-ethnic study of atherosclerosis [44,47], the prevalence of AAC was also the highest in Caucasians $(79 \%)$ compared to AAs $(62 \%, p=0.0001)$. In contrast, the Dallas Heart Study showed a similar prevalence of coronary calcium in AA and Caucasian men and women [48]. In the Framingham Osteoporosis study [42], the prevalence of AAC was 37\% in men and $27 \%$ in women at baseline (mean age 54). At follow up after 25 years, the prevalence was $86 \%$ in both genders (mean age 79).

We used the Kauppila score for grading AAC, which is a validated, cost-effective scoring system. In a recent study, the Kauppila score has been predictive of carotid plaque $(\mathrm{CP})$ and cardiac valvular calcification (CVC) with moderate accuracy in ESRD patients [49]. Additionally, there is strong evidence that AAC is predictive of CVD events and death in the general population [50]. Most studies in the past have also used CT imaging for the quantification of aortic calcification.

In our study, extended aortic calcification $(A A C \geq 5)$ scores were not associated with serum $25(\mathrm{OH}) \mathrm{D}$ levels or bone turnover markers such as c-terminal telopeptide, bone-specific alkaline phosphatase or serum calcium, and phosphate. However, a positive association was seen with PTH. Several clinical and experimental trials have shown a direct effect of PTH on atherogenesis via vascular remodeling and its direct actions on smooth muscle cells [51,52]. In a recent study by Pepe at al. [51], a significantly higher prevalence of AAC was noted in postmenopausal women with primary hyperparathyroidism after accounting for traditional risk factors. Another study [53] showed PTH as an independent predictor of aortic valve calcification in primary hyperparathyroidism patients after adjusting for risk factors. PTH levels are known to be higher in AA women and our study showed a positive association between PTH and extended AAC scores [54]. However, when PTH values were analyzed separately by group, it was revealed that the relationship of AAC to PTH over time was significant in the placebo group but not the vitamin D group. We previously reported that vitamin D supplementation suppressed PTH levels [35]. Vitamin D deficiency and secondary hyperparathyroidism are more prevalent in AA women compared to whites, particularly obese AA women. Higher PTH levels correlate with fat mass, fat distribution, and anthropometric measures in AA women $[55,56]$. The association between PTH, AAC and vitamin D needs to be explored further.

In addition, a positive association was noted between the serum Ca*P product and AAC in the vitamin $\mathrm{D}$ group with a trend in the placebo group. The association between an elevated $\mathrm{Ca}^{*} \mathrm{P}$ product and vascular calcification is well known, even in the absence of hyperphosphatemia [57-59].

Our study had several strengths and weaknesses. To the best of our knowledge, it is the first study of the effect of high-dose vitamin D supplementation on the progression of AAC in a healthy population, particularly older AA women. The study population included healthy volunteers, as we accounted for the traditional cardiovascular risk factors. This study was powered for changes in BMD (not AAC), so it is possible that a difference in AAC could have gone undetected. The prevalence of AAC and extended AAC was low for the same reason, and most likely explains the lack of any significant association seen in the present study. In comparison, a recent study of 429 Caucasian women (mean age 60 years) living in the Rabat area of Morocco had an extended AAC (AAC24 $\geq 5$ ) prevalence of $7.9 \%[60]$.

\section{Conclusions}

There was no relationship between baseline $25(\mathrm{OH}) \mathrm{D}$ and AAC. Raising serum $25(\mathrm{OH}) \mathrm{D}$ to levels above $75 \mathrm{nmol} / \mathrm{L}$ did not influence the progression of AAC in older black women. There was an association between PTH and AAC in the placebo group, which should be explored further. 
Author Contributions: Conceptualization, J.F.A.; Methodology J.F.A.; Writing-Original Draft Preparation, J.F.A. and S.B.; Writing-Review and Editing, J.F.A., S.B. and S.I.; Supervised investigation, M.M.; Visualization, J.F.A.; Supervision, J.F.A.; Project Administration, J.F.A.; Funding Acquisition, J.F.A.; Interpretation of scans, S.B.; Data analysis, S.I. All authors have read and agreed to the published version of the manuscript.

Funding: This research was funded by the National Institutes of Health RO1-AG032440 grant. We thank the staff at the Bone Mineral Research Center at NYU Winthrop Hospital for their dedication to this study.

Conflicts of Interest: The authors declare no conflict of interest.

\section{References}

1. Hofbauer, L.C.; Brueck, C.C.; Shanahan, C.M.; Schoppet, M.; Dobnig, H. Vascular calcification and osteoporosis-from clinical observation towards molecular understanding. Osteoporos. Int. 2006, 18, 251-259. [CrossRef] [PubMed]

2. Kim, K.J.; Kim, K.M.; Park, K.H.; Choi, H.S.; Rhee, Y.; Lee, Y.-H.; Cha, B.-S.; Kim, D.Y.; Oh, S.M.; Brown, J.K.; et al. Aortic Calcification and Bone Metabolism: The Relationship between Aortic Calcification, BMD, Vertebral Fracture, 25-Hydroxyvitamin D, and Osteocalcin. Calcif. Tissue Int. 2012, 91, 370-378. [CrossRef] [PubMed]

3. Persy, V.; D'Haese, P. Vascular calcification and bone disease: The calcification paradox. Trends Mol. Med. 2009, 15, 405-416. [CrossRef] [PubMed]

4. Vogt, M.T.; Valentin, R.S.; Forrest, K.Y.-Z.; Nevitt, M.C.; Cauley, J.A. Bone Mineral Density and Aortic Calcification: The Study of Osteoporotic Fractures. J. Am. Geriatr. Soc. 1997, 45, 140-145. [CrossRef]

5. Nargesi, A.A.; Heidari, B.; Esteghamati, S.; Hafezi-Nejad, N.; Sheikhbahaei, S.; Pajouhi, A.; Nakhjavani, M.; Esteghamati, A. Contribution of vitamin D deficiency to the risk of coronary heart disease in subjects with essential hypertension. Atherosclerosis 2016, 244, 165-171. [CrossRef]

6. Wang, J.; Zhou, J.J.; Robertson, G.R.; Lee, V.W. Vitamin D in Vascular Calcification: A Double-Edged Sword? Nutrients 2018, 10, 652. [CrossRef]

7. Zagura, M.; Serg, M.; Kampus, P.; Zilmer, M.; Eha, J.; Unt, E.; Lieberg, J.; Cockcroft, J.; Kals, J. Aortic Stiffness and Vitamin D are Independent Markers of Aortic Calcification in Patients with Peripheral Arterial Disease and in Healthy Subjects. Eur. J. Vasc. Endovasc. Surg. 2011, 42, 689-695. [CrossRef]

8. Aggarwal, R.; Akhthar, T.; Jain, S.K. Coronary artery disease and its association with Vitamin D deficiency. J. Mid-Life Health 2016, 7, 56-60. [CrossRef]

9. Kunadian, V.; Ford, G.A.; Bawamia, B.; Qiu, W.; Manson, J.E. Vitamin D deficiency and coronary artery disease: A review of the evidence. Am. Hear. J. 2014, 167, 283-291. [CrossRef]

10. Welles, C.C.; Whooley, M.A.; Karumanchi, S.A.; Hod, T.; Thadhani, R.; Berg, A.H.; Ix, J.H.; Mukamal, K.J. Vitamin D deficiency and cardiovascular events in patients with coronary heart disease: Data from the Heart and Soul Study. Am. J. Epidemiol. 2014, 179, 1279-1287. [CrossRef]

11. Razzaque, M. The dualistic role of vitamin D in vascular calcifications. Kidney Int. 2010, 79, 708-714. [CrossRef] [PubMed]

12. Wolisi, G.O.; Moe, S.M. Vitamin D in health and disease: The Role of Vitamin D in Vascular Calcification in Chronic Kidney Disease. Semin. Dial. 2005, 18, 307-314. [CrossRef] [PubMed]

13. Zittermann, A.; Schleithoff, S.S.; Koerfer, R. Vitamin D and vascular calcification. Curr. Opin. Lipidol. 2007, 18, 41-46. [CrossRef] [PubMed]

14. Kauppila, L. New indices to classify location, severity and progression of calcific lesions in the abdominal aorta: A 25-year follow-up study. Atherosclerosis 1997, 132, 245-250. [CrossRef]

15. Golestani, R.; Tio, R.; Zeebregts, C.J.; Zeilstra, A.; Dierckx, R.A.; Boersma, H.H.; Hillege, H.L.; Slart, R.H.J.A. Abdominal aortic calcification detected by dual X-ray absorptiometry: A strong predictor for cardiovascular events. Ann. Med. 2010, 42, 539-545. [CrossRef]

16. Norman, P.E.; Powell, J.T. Vitamin D and cardiovascular disease. Circ. Res. 2014, 114, 379-393. [CrossRef]

17. Okuno, S.; Ishimura, E.; Kitatani, K.; Fujino, Y.; Kohno, K.; Maeno, Y.; Maekawa, K.; Yamakawa, T.; Imanishi, Y.; Inaba, M.; et al. Presence of Abdominal Aortic Calcification Is Significantly Associated With All-Cause and Cardiovascular Mortality in Maintenance Hemodialysis Patients. Am. J. Kidney Dis. 2007, 49, 417-425. [CrossRef] 
18. Szulc, P. Abdominal aortic calcification: A reappraisal of epidemiological and pathophysiological data. Bone 2016, 84, 25-37. [CrossRef]

19. Wilson, P.W.F.; Kauppila, L.I.; O’Donnell, C.J.; Kiel, D.P.; Hannan, M.; Polak, J.M.; Cupples, L.A. Abdominal Aortic Calcific Deposits Are an Important Predictor of Vascular Morbidity and Mortality. Circulation 2001, 103, 1529-1534. [CrossRef]

20. Barreto, D.V.; Barreto, F.C.; Liabeuf, S.; Temmar, M.; Boitte, F.; Choukroun, G.; Fournier, A.; Massy, Z.A. Vitamin D affects survival independently of vascular calcification in chronic kidney disease. Clin. J. Am. Soc. Nephrol. 2009, 4, 1128-1135. [CrossRef]

21. McCullough, P.A.; Sandberg, K.R.; Dumler, F.; Yanez, J.E. Determinants of coronary vascular calcification in patients with chronic kidney disease and end-stage renal disease: A systematic review. J. Nephrol. 2004, 17, 205-215. [PubMed]

22. Mizobuchi, M.; Ogata, E.; Koiwa, F.; Kinugasa, E.; Akizawa, T. Vitamin D and vascular calcification in chronic kidney disease. Bone 2009, 45, S26-S29. [CrossRef] [PubMed]

23. Rodriguez, M.; Martinez-Moreno, J.M.; Rodríguez-Ortiz, M.E.; Muñoz-Castañeda, J.R.; Almadén, Y. Vitamin D and Vascular Calcification in Chronic Kidney Disease. Kidney Blood Press. Res. 2011, 34, 261-268. [CrossRef] [PubMed]

24. Sugden, J.; Davies, J.I.; Witham, M.; Morris, A.D.; Struthers, A.D. Vitamin D improves endothelial function in patients with Type 2 diabetes mellitus and low vitamin D levels. Diabet. Med. 2008, 25, 320-325. [CrossRef] [PubMed]

25. Tarcin, O.; Yavuz, D.G.; Ozben, B.; Telli, A.; Ogunc, A.V.; Yuksel, M.; Toprak, A.; Yazici, D.; Sancak, S.; Deyneli, O.; et al. Effect of Vitamin D Deficiency and Replacement on Endothelial Function in Asymptomatic Subjects. J. Clin. Endocrinol. Metab. 2009, 94, 4023-4030. [CrossRef] [PubMed]

26. Levin, A.; Bakris, G.; Molitch, M.; Smulders, M.; Tian, J.; Williams, L.; Andress, D. Prevalence of abnormal serum vitamin D, PTH, calcium, and phosphorus in patients with chronic kidney disease: Results of the study to evaluate early kidney disease. Kidney Int. 2007, 71, 31-38. [CrossRef]

27. Mehrotra, R.; Kermah, D.A.; Salusky, I.B.; Wolf, M.S.; Thadhani, R.I.; Chiu, Y.-W.; Martins, D.; Adler, S.G.; Norris, K.C. Chronic kidney disease, hypovitaminosis D, and mortality in the United States. Kidney Int. 2009, 76, 977-983. [CrossRef]

28. Moe, S.M.; Chen, N.X. Mechanisms of Vascular Calcification in Chronic Kidney Disease: Figure 1. J. Am. Soc. Nephrol. 2007, 19, 213-216. [CrossRef]

29. Schlieper, G.; Schurgers, L.; Brandenburg, V.; Reutelingsperger, C.; Floege, J. Vascular calcification in chronic kidney disease: An update. Nephrol. Dial. Transpl. 2015, 31, 31-39. [CrossRef]

30. Vervloet, M.G.; Cozzolino, M. Vascular calcification in chronic kidney disease: Different bricks in the wall? Kidney Int. 2017, 91, 808-817. [CrossRef]

31. Hanada, S.; Ando, R.; Naito, S.; Kobayashi, N.; Wakabayashi, M.; Hata, T.; Sasaki, S. Assessment and significance of abdominal aortic calcification in chronic kidney disease. Nephrol. Dial. Transpl. 2010, 25, 1888-1895. [CrossRef] [PubMed]

32. Honkanen, E.; Kauppila, L.; Wikström, B.; Rensma, P.L.; Krzesinski, J.-M.; Aasarod, K.; Verbeke, F.; Jensen, P.B.; Mattelaer, P.; Volck, B.; et al. Abdominal aortic calcification in dialysis patients: Results of the CORD study. Nephrol. Dial. Transpl. 2008, 23, 4009-4015. [CrossRef] [PubMed]

33. Aloia, J.; Mikhail, M.; Fazzari, M.; Islam, S.; Ragolia, L.; Guralnik, J.; Ragolia, L. Physical Performance and Vitamin D in Elderly Black Women-The PODA Randomized Clinical Trial. J. Clin. Endocrinol. Metab. 2018, 104, 1441-1448. [CrossRef] [PubMed]

34. Dhaliwal, R.; Mikhail, M.; Usera, G.; Stolberg, A.; Islam, S.; Ragolia, L.; Aloia, J.F. The relationship of Physical performance and Osteoporosis prevention with vitamin D in older African Americans (PODA). Contemp. Clin. Trials 2018, 65, 39-45. [CrossRef]

35. Aloia, J.F.; Fazzari, M.; Islam, S.; Mikhail, M.; Shieh, A.; Katumuluwa, S.; Dhaliwal, R.; Stolberg, A.; Usera, G.; Ragolia, L. Vitamin D Supplementation in Elderly Black Women Does Not Prevent Bone Loss: A Randomized Controlled Trial. J. Bone Min. Res. 2018, 33, 1916-1922. [CrossRef]

36. Brahmbhatt, S.; Islam, S.; Aloia, J.F. OR13-6 Hyperparathyroidism and Abdominal Aortic Calcification in Older African American Women: PODA Trial. J. Endocr. Soc. 2019, 3 (Suppl. S1), OR13-6. [CrossRef] 
37. Owusu, J.E.; Islam, S.; Katumuluwa, S.S.; Stolberg, A.R.; Usera, G.L.; Anwarullah, A.A.; Shieh, A.; Dhaliwal, R.; Ragolia, L.; Mikhail, M.B.; et al. Cognition and Vitamin D in Older African-American Women- Physical performance and Osteoporosis prevention with vitamin D in older African Americans Trial and Dementia. J. Am. Geriatr. Soc. 2018, 67, 81-86. [CrossRef]

38. Aloia, J.; Rubinova, R.; Fazzari, M.; Islam, S.; Mikhail, M.; Ragolia, L. Vitamin D and Falls in Older African American Women: The PODA Randomized Clinical Trial. J. Am. Geriatr. Soc. 2019, 67, 1043-1049. [CrossRef]

39. Aloia, J.; Islam, S.; Mikhail, M. Vitamin D and Acute Respiratory Infections-The PODA Trial. Open Forum Infect. Dis. 2019, 6, ofz228. [CrossRef]

40. Dhaliwal, R.; Islam, S.; Mikhail, M.; Ragolia, L.; Aloia, J. Effect of vitamin D on bone strength in older African Americans: A randomized controlled trial. Osteoporos. Int. 2020. [CrossRef]

41. ClinicalTrials.gov. Available online: https://www.clinicaltrials.gov/ (accessed on 23 March 2020).

42. Kiel, D.P.; Kauppila, L.I.; Cupples, L.A.; Hannan, M.T.; O’Donnell, C.J.; Wilson, P.W.F. Bone loss and the progression of abdominal aortic calcification over a 25 year period: The Framingham Heart Study. Calcif. Tissue Int. 2001, 68, 271-276. [CrossRef] [PubMed]

43. Schousboe, J.T.; Wilson, K.E.; Hangartner, T.N. Detection of Aortic Calcification during Vertebral Fracture Assessment (VFA) Compared to Digital Radiography. PloS ONE 2007, 2, 715. [CrossRef] [PubMed]

44. Farhat, G.N.; Cauley, J.A.; Matthews, K.; Newman, A.B.; Johnston, J.; Mackey, R.; Edmundowicz, D.; Sutton-Tyrrell, K. Volumetric BMD and Vascular Calcification in Middle-Aged Women: The Study of Women's Health Across the Nation. J. Bone Min. Res. 2006, 21, 1839-1846. [CrossRef] [PubMed]

45. Freedman, B.I.; Register, T.C. Effect of race and genetics on vitamin D metabolism, bone and vascular health. Nat. Rev. Nephrol. 2012, 8, 459-466. [CrossRef] [PubMed]

46. Freedman, B.I.; Wagenknecht, L.E.; Hairston, K.G.; Bowden, N.W.; Carr, J.J.; Hightower, R.C.; Gordon, E.J.; Xu, J.; Langefeld, C.D.; Divers, J. Vitamin D, adiposity, and calcified atherosclerotic plaque in african-americans. J. Clin. Endocrinol. Metab. 2010, 95, 1076-1083. [CrossRef] [PubMed]

47. Wong, N.D.; Lopez, V.A.; Allison, M.; Detrano, R.C.; Blumenthal, R.S.; Folsom, A.R.; Ouyang, P.; Criqui, M.H. Abdominal aortic calcium and multi-site atherosclerosis: The Multiethnic Study of Atherosclerosis. Atherosclerosis 2010, 214, 436-441. [CrossRef] [PubMed]

48. Jain, T.; Peshock, R.; McGuire, D.K.; Willett, D.; Yu, Z.; Vega, G.L.; Guerra, R.; Hobbs, H.H.; Grundy, S.M. African Americans and Caucasians have a similar prevalence of coronary calcium in the Dallas Heart Study. J. Am. Coll. Cardiol. 2004, 44, 1011-1017. [CrossRef]

49. Abraham, G.; Shantha, G.P.S.; Kumar, A.A.; Mancha, A.; Koshi, R.; Christopher, M. Is abdominal aortic calcification score a cost-effective screening tool to predict atherosclerotic carotid plaque and cardiac valvular calcification in patients with end-stage renal disease? Indian J. Nephrol. 2012, 22, 431-437. [CrossRef]

50. Gonçalves, F.B.; Voûte, M.; Hoeks, S.E.; Chonchol, M.B.; Boersma, E.E.; Stolker, R.J.; Verhagen, H.J.M. Calcification of the abdominal aorta as an independent predictor of cardiovascular events: A meta-analysis. Heart 2012, 98, 988-994. [CrossRef]

51. Pepe, J.; Diacinti, D.; Fratini, E.; Nofroni, I.; D’Angelo, A.; Pilotto, R.; Savoriti, C.; Colangelo, L.; Raimo, O.; Cilli, M.; et al. High prevalence of abdominal aortic calcification in patients with primary hyperparathyroidism as evaluated by Kauppila score. Eur. J. Endocrinol. 2016, 175, 95-100. [CrossRef]

52. Rashid, G.; Bernheim, J.; Green, J.; Benchetrit, S. Parathyroid hormone stimulates endothelial expression of atherosclerotic parameters through protein kinase pathways. Am. J. Physiol. Physiol. 2007, 292, F1215-F1218. [CrossRef] [PubMed]

53. Iwata, S.; Walker, M.D.; di Tullio, M.R.; Hyodo, E.; Jin, Z.; Liu, R.; Sacco, R.L.; Homma, S.; Silverberg, S.J. Aortic valve calcification in mild primary hyperparathyroidism. J. Clin. Endocrinol. Metab. 2012, 97, 132-137. [CrossRef] [PubMed]

54. Perry, H.M., 3rd; Horowitz, M.; Morley, J.E.; Fleming, S.; Jensen, J.; Caccione, P.; Miller, D.K.; Kaiser, F.E.; Sundarum, M. Aging and bone metabolism in African American and Caucasian women. J. Clin. Endocrinol. Metab. 1996, 81, 1108-1117. [PubMed]

55. Valiña-Tóth, A.L.B.; Lai, Z.; Yoo, W.; Abou-Samra, A.; Gadegbeku, C.A.; Flack, J.M. Relationship of vitamin $\mathrm{D}$ and parathyroid hormone with obesity and body composition in African Americans. Clin. Endocrinol. 2009, 72, 595-603. [CrossRef] [PubMed] 
56. Liu, J.; Musani, S.K.; Bidulescu, A.; Carr, J.J.; Wilson, J.G.; Taylor, H.A.; Fox, C.S. Fatty liver, abdominal adipose tissue and atherosclerotic calcification in African Americans: The Jackson Heart Study. Atherosclerosis 2012, 224, 521-525. [CrossRef] [PubMed]

57. Osuka, S.; Razzaque, M. Can features of phosphate toxicity appear in normophosphatemia? J. Bone Min. Metab. 2012, 30, 10-18. [CrossRef]

58. Ganesh, S.K.; Stack, A.G.; Levin, N.W.; Hulbert-Shearon, T.; Port, F.K. Association of elevated serum PO(4), $\mathrm{Ca} \times \mathrm{PO}(4)$ product, and parathyroid hormone with cardiac mortality risk in chronic hemodialysis patients. J. Am. Soc. Nephrol. 2001, 12, 2131-2138.

59. El-Gamasy, M.A.; El-Shehaby, W.A.; Mabrouk, M.M. Early predictors of cardiac dysfunction in Egyptian children with chronic kidney disease. Ann. Pediatr. Cardiol. 2019, 12, 10-17. [CrossRef]

60. El Maghraoui, A.; Hamza, T.; Sadni, S.; El Maataoui, A.; Majjad, A.; Rezqi, A.; Ouzzif, Z.; Mounach, A. Vitamin D status and abdominal aortic calcification in postmenopausal women. J. Bone Min. Metab. 2017, 36, 229-237. [CrossRef]

(C) 2020 by the authors. Licensee MDPI, Basel, Switzerland. This article is an open access article distributed under the terms and conditions of the Creative Commons Attribution (CC BY) license (http://creativecommons.org/licenses/by/4.0/). 